\title{
Pengaruh Pengungkapan Corporate Social Responsibility terhadap Manajemen Laba Riil dengan Mekanisme Corporate Governance sebagai Pemoderasi
}

\author{
Debby Kurniawati \\ Universitas Katolik Widya Mandala Surabaya \\ debbykurniawati278@gmail.com
}

This study aims to analyze the effect of CSR disclosure on real earning management with corporate governance mechanism as a moderating variable. The research object is manufacturing companies listed on the Indonesia Stock Exchange in 2016-2019. The samples are 48 manufacturing companies selected with purposive sampling techniques. The results show the greater disclosure of CSR, the smaller real earnings management proxied by abnormal operating cash flows, abnormal production costs, and abnormal discretionary costs; the size of managerial ownership cannot strengthen the effect of CSR disclosure on real earnings management proxied by abnormal operating cash flows, abnormal production costs, and abnormal discretionary costs; and institutional ownership can strengthen the relationship between CSR disclosure and real earnings management proxied by abnormal production costs, but institutional ownership cannot strengthen the relationship between CSR disclosure and real earnings management proxied by abnormal operating cash flows and abnormal discretionary costs.

Keywords: CSR disclosure, real earning management, managerial ownership, institutional ownership

\section{Pendahuluan}

Laba merupakan salah satu indikator penting dalam menentukan dan mengevaluasi kinerja perusahaan serta menjadi pusat perhatian bagi para investor yang membantu dalam pengambilan keputusan investasi. Sebuah perusahaan pada umumnya memiliki dorongan untuk memberikan informasi kepada pihak eksternal, 
termasuk informasi mengenai laba. Proses yang dilakukan perusahaan untuk memperoleh laba seringkali tidak menjadi perhatian utama bagi investor atau pengguna laporan lainnya, sehingga hal ini membuka celah bagi manajemen untuk melakukan praktik manajemen laba. Manajemen laba diartikan sebagai tindakan yang dilakukan oleh manajemen perusahaan untuk mengubah angka laba dengan mengandalkan pengetahuan serta pengendalian atas operasi dan sistem pelaporan keuangan dalam perusahaan sehingga menyebabkan informasi laba terdistorsi, yang dilakukan untuk mencapai tujuan tertentu (Buertey, Sun, Lee, dan Hwang., 2019. Manajemen laba dapat dibagi menjadi dua pendekatan yaitu manajemen laba akrual dan manajemen laba riil. Manajemen laba akrual dilakukan di akhir periode akuntansi saat manajemen menyadari bahwa laba yang ditargetkan tidak tercapai. Manajemen laba riil pada umunya dilakukan selama kegiatan operasi normal perusahaan seharihari dalam periode akuntansi untuk mencapai target laba (Majid, dkk., 2020). Menurut Puspitasari dan Nugrahanti (2016) penggunaan manajemen laba riil oleh perusahaan ditujukan untuk menghindari investigasi yang dilakukan oleh auditor karena manajemen laba riil dapat dilakukan sepanjang periode akuntansi dan sulit dibedakan dengan keputusan efisiensi bisnis sehingga akan sulit dideteksi oleh auditor.

Dalam lingkup global, permasalahan akibat adanya evaluasi kinerja berbasis laba terjadi di beberapa perusahaam, seperti Enron, Worldcom, dan Xerox. Manajemen laba juga banyak terjadi di perusahaan-perusahaan besar dalam negeri. Salah satu kasus manajemen laba yaitu dilakukan oleh PT Garuda Indonesia Tbk yang membukukan laba lebih besar senilai Rp 11,56 miliar pada tahun 2018. Manipulasi laba yang dilakukan oleh PT Garuda Indonesia Tbk dikarenakan adanya pencatatan piutang dari transaksi dengan PT Mahata sebagai pendapatan. Kasus di atas merupakan suatu rekayasa akuntansi untuk membuat laporan perusahaan terlihat lebih baik daripada yang sebenarnya.

Dewasa ini fokus utama perusahaan seharusnya tidak hanya memperoleh laba, namun juga perlu untuk melakukan aktivitas-aktivitas sosial atau corporate social responsibility (CSR). Para investor akan mempertimbangkan kontribusi apa yang dilakukan perusahaan terhadap lingkungan sosial di sekitarnya. CSR juga telah mendapat perhatian dari berbagai kalangan, termasuk pemerintah. Mengingat pentingnya CSR untuk mencapai keuntungan kompetitif perusahaan, maka pengungkapan CSR perlu untuk disajikan secara transparan. Perusahaan yang melakukan pengungkapan CSR secara transparan mencerminkan bahwa perusahaan tersebut memiliki komitmen yang kuat terhadap lingkungan sosial di sekitarnya (Sembiring, 2017).

Manajemen laba yang dilakukan oleh manajer perusahaan dapat dikurangi atau diminimalisir dengan adanya penerapan tata kelola perusahaan atau corporate governance (CG) yang baik (Ardiani dan Sudana, 2018). Corporate governance merupakan konsep untuk meningkatkan kinerja perusahaan melalui pengawasan terhadap aktivitas manajemen. Corporate governance dapat diukur dengan menggunakan 
mekanisme. Mekanisme CG dapat dibagi menjadi mekanisme internal dan eksternal. Mekanisme CG yang digunakan dalam penelitian ini yaitu kepemilikan manajeral dan kepemilikan institusional. Dengan kepemilikan manajemen, maka manajemen akan berusaha meningkatkan kinerjanya untuk kepentingan pemegang saham dan untuk kepentingannya sendiri. Kepemilikan institusional berperan penting dalam meminimalisasi konflik keagenan yang terjadi antara manajer dan pemegang saham.

Penelitian ini bertujuan untuk menguji dan menganalisis pengaruh pengungkapan CSR terhadap manajemen laba riil dengan mekanisme CG sebagai variabel pemoderasi. Secara akademis, penelitian ini digunakan sebagai referensi bagi peneliti selanjutnya yang akan meneliti topik sejenis dan secara praktis penelitian ini dapat menjadi referensi bagi para pemangku kepentingan perusahaan agar memperhatikan sejauh mana perusahaan melakukan tanggung jawab sosial terhadap lingkungannya dan seberapa lengkap perusahaan mengungkapkan praktik CSRnya serta untuk menentukan apakah perusahaan pernah melakukan manajemen laba dan sejauh mana pengungkapan CSR bisa mempengaruhi praktik manajemen laba.

\section{Tinjauan Pustaka}

\subsection{Teori Keagenan}

Teori keagenan memaparkan tentang hubungan antara principal dan agent, di mana principal memberikan kewenangan kepada agent untuk menjalankan operasionalisasi perusahaan (Duwu, Daat, dan Andriati, 2018). Teori keagenan membahas mengenai masalah-masalah yang muncul dalam perusahaan berkaitan dengan pemisahan kepentingan antara pemegang saham dan manajer serta menekankan bagaimana cara meminimalkan masalah tersebut (Panda dan Leepsa, 2017). Manajer sebagai pihak yang terlibat dalam pengelolaan perusahaan secara langsung memiliki informasi yang lebih banyak dan beragam mengenai kondisi perusahaan yang sebenarnya dibandingkan dengan pemegang saham. Perbedaan kepentingan antara manajer dan pemegang saham juga membuka peluang bagi manajer untuk melakukan praktik manajemen laba termasuk manajemen laba riil dalam kegiatan operasional perusahaan, di mana manajer berfokus pada besarnya insentif yang diterima saat laba yang dilaporkan perusahaan besar. Teori keagenan menempatkan pengungkapkan sebagai mekanisme untuk mengurangi biaya yang timbul dari adanya konflik antara manajer dan pemegang saham (Suhardjanto dan Wardhani, 2010). Oleh karena itu manajemen perusahaan diharapkan dapat melakukan pengungkapan yang transparan mengenai aktivitas dan kondisi perusahaan, termasuk pengungkapan CSR. Dengan dilakukannya pengungkapan CSR principal akan lebih percaya bahwa agen tidak melakukan kegiatan yang akan menguntungkan diri sendiri sehingga dapat meminimalkan konflik kepentingan dan biaya keagenan. 


\subsection{Manajemen Laba}

Manajemen laba merupakan merupakan tindakan yang dilakukan manajemen perusahaan untuk mempengaruhi atau merekayasa angka laba dengan mengandalkan pengetahuan serta pengendalian atas operasi dan sistem pelaporan keuangan dalam perusahaan sehingga menyebabkan informasi laba terdistorsi (Buertey, dkk., 2019). Manajemen laba dapat dilakukan oleh manajer perusahaan dengan meratakan, menaikkan, atau bahkan menurunkan angka laba. Informasi laba tak jarang menjadi perhatian utama bagi investor atau pemegang saham sehingga mendorong manajemen untuk mempercantik angka dalam laporan keuangan demi keuntungan pribadi (Majid, dkk., 2020). Praktik manajemen laba dapat menyebabkan informasi yang disajikan dalam laporan keuangan menjadi tidak wajar, bias, dan tidak mampu menggambarkan kondisi perusahaan yang sebenarnya. Manajemen laba melibatkan adanya salah saji informasi laba dalam laporan keuangan yang disengaja dengan memanfaatkan standar akuntansi (Magrath dan Weld, 2002).

\subsection{Manajemen Laba Riil}

Manajemen laba dibagi menjadi dua yaitu manajemen laba akrual dan manajemen laba riil. Manajemen laba akrual dilakukan dengan merekayasa discretionary accrual yang tidak mempengaruhi arus kas secara lagsung dan pada umumnya dilakukan pada akhir periode akuntansi. Dalam penelitian ini, manajemen laba yang diteliti yaitu berfokus pada manajemen laba riil. Manajemen laba riil merupakan perekayasaan angka laba yang dilakukan melalui aktivitas riil yaitu melalui kegiatan bisnis normal yang pada umumnya berhubungan dengan kegiatan operasional perusahaan dan dapat dilakukan selama periode berjalan (Majid, dkk., 2020). Menurut Roychowdhury (2006), manajemen laba riil dapat dilakukan menggunakan tiga teknik berikut ini:

\section{a. Pemanipulasian Penjualan (Sales Manipulation)}

Dalam teknik ini angka laba direkayasa dengan memanipulasi penjualan yaitu meningkatkan penjualan secara besar-besaran melalui berbagai cara, misalnya menawarkan diskon yang besar maupun memberikan syarat kredit yang mudah atau kelonggaran dalam jatuh tempo pembayaran. Hal ini akan membantu manajer untuk meningkatkan penjualan, sehingga laba kotor juga akan meningkat namun terjadi penurunan arus kas operasi. Laba yang meningkat ini juga akan membuat kinerja manajer terlihat lebih baik sehingga manajer memiliki kesempatan untuk mendapatkan bonus lebih besar (Mukhtar, 2016).

\section{b. Produksi yang Berlebih (Overproduction)}

Dalam teknik ini manajer akan melakukan produksi dalam jumlah yang besar melebihi jumlah permintaan yang diterima maupun yang diharapkan perusahaan untuk 
mencapai target laba tertentu. Produksi dalam jumlah besar akan menurunkan biaya overhead tetap per unit sehingga biaya per unit barang yang diproduksi dan harga pokok penjualan akan lebih kecil dan mengakibatkan laba atau keuntungan operasi yang didapatkan perusahaan akan meningkat (Majid, dkk., 2020).

c. Pengurangan Biaya Diskresioner (Reduction of Discretionary Expenditures) Dalam teknik ini manajer akan mengurangi biaya-biaya diskresioner yang dibebankan dalam periode berjalan untuk mencapai target laba tertentu. Biaya diskresioner merupakan biaya yang tidak berkaitan langsung dengan produk dan biaya yang outputnya tidak dapat dinyatakan dalam satuan moneter. Biaya diskresioner ini meliputi biaya riset dan pengembangan (R\&D), biaya administrasi dan umum, biaya iklan, dan biaya pemeliharaan. Dengan pengurangan biaya dikresioner ini maka laba periode berjalan dapat meningkat (Majid, dkk., 2020).

\subsection{Pengungkapan Corporate Social Responsibility (CSR)}

Corporate Social Responsibility (CSR) merupakan komitmen organisasi bisnis untuk melakukan tindakan etis dan berkontribusi terhadap pengembangan ekonomi komunitas tertentu ataupun masyarakat luas serta peningkatan taraf hidup karyawan beserta keluarganya. CSR bertujuan untuk menjadikan perusahaan tidak hanya berfokus pada single-bottom-line yang berupa kinerja keuangan saja, namun lebih berfokus pada konsep tripple-bottom-line (TBL) yang mencakup aspek keuangan, kehidupan sosial, dan lingkungan (Kalbuana, Sutadipraja, Purwanti, dan Santoso., 2019). Di Indonesia, regulasi tentang CSR atau tanggung jawab sosial telah diatur dalam Pasal 74 UU Nomor 40 tahun 2007 tentang Perseroan Terbatas yang menyatakan bahwa tanggung jawab sosial dan lingkungan wajib dilakukan oleh perseroan yang bergerak di bidang atau berkaitan dengan sumber daya alam. Perseroan yang melanggar ataupun tidak menjalankan tanggung jawab sosial dan lingkungan akan dikenai sanksi sesuai peraturan perundang-undangan yang berlaku. Selain itu, diterbitkan pula PP No. 47 tahun 2012 yang menyatakan pelaksanaan tanggung jawab sosial dan lingkungan dipertanggungjawabkan kepada RUPS dan dicantumkan dalam laporan tahunan (Putri dan Rohman, 2016). Hal ini menunjukkan bahwa praktik CSR juga telah mendapat perhatian dari pemerintah.

Dalam melakukan praktik CSR perusahaan perlu untuk melakukan pengungkapan CSR sebagai bentuk pertanggungjawaban atas kegiatan CSR. Dalam penelitian ini, pengungkapan CSR menggunakan indikator GRI-G4 yang diresmikan oleh lembaga Global Reporting Initiative (GRI). GRI-G4 digunakan karena merupakan item pengungkapan yang lebih luas dan lengkap, yang secara total terdiri dari 91 item pengungkapan dan terbagi menjadi tiga kategori, yaitu ekonomi, lingkungan, dan sosial yang dapat dirinci sebagai berikut (Sembiring, 2017): 
a. Kategori ekonomi terdiri dari 4 aspek yaitu kinerja ekonomi, keberadaan di pasar, dampak ekonomi tidak langsung, dan praktik pengadaan. Secara keseluruhan kategori ekonomi terdiri dari 9 item pengungkapan.

b. Kategori lingkungan terdiri dari 12 aspek yaitu bahan, energi, air, keanekaragaman hayati, emisi, efluen dan limbah, produk dan jasa, kepatuhan, transportasi, asesmen pemasok atas lingkungan, serta mekanisme pengaduan masalah lingkungan. Secara keseluruhan kategori lingkungan terdiri atas 34 item pengungkapan.

c. Kategori sosial terdiri dari empat sub kategori yaitu ketenagakerjaan dan kenyamanan bekerja, hak asasi manusia, masyarakat, dan tanggung jawab atas produk. Secara keseluruhan kategori sosial terdiri atas 30 aspek dan 48 indikator.

\subsection{Corporate governance}

Corporate governance (CG) merupakan konsep untuk meningkatkan kinerja perusahaan melalui pengawasan terhadap tindakan manajemen untuk menjamin akuntabilitas, transparansi, responsibilitas, independensi, kewajaran, dan kesetaraan perusahaan. CG memiliki manfaat untuk meningkatkan kinerja perusahaan melalui proses pengambilan keputusan yang lebih baik, meningkatkan efisiensi aktivitas operasional perusahaan, memudahkan perusahaan untuk memperoleh dana pembiayaan yang lebih murah, meningkatkan kepercayaan investor, dan meningkatkan nilai shareholder serta dividen (FCGI, 2001). Good corporate governance (GCG) merupakan seperangkat aturan untuk mengatur hubungan antara pihak internal dan eksternal perusahaan serta sistem pengaturan dan pengendalian perusahaan (Ardiani dan Sudana 2018). GCG memiliki prinsip-prinsip yang terdiri dari lima asas yaitu (Manossoh, 2016: 14-16): transparansi, akuntabilitas, responsibilitas, independensi, dan kesetaraan.

\subsection{Mekanisme Corporate Governance}

Mekanisme CG merupakan prosedur dan hubungan yang jelas antara pihak pengambil keputusan dengan pihak yang mengontrol atau mengawasi keputusan tersebut. Mekanisme CG diharapkan mampu mengendalikan biaya keagenan dan mengurangi konflik keagenan. Mekanisme CG dikategorikan menjadi mekanisme internal dan eksternal. Mekanisme internal meliputi kepemilikan manajerial, struktur dewan komisaris, dan kompensasi ekslusif. Mekanisme eksternal meliputi kepemilikan institusional, pasar untuk kontrol perusahaan, dan tingkat pendanaan dengan hutang (Launa dan Respati, 2014). Dalam penelitian ini, mekanisme CG yang digunakan yaitu kepemilikan manajerial dan kepemilikan institusional. Kepemilikan manajerial merupakan kepemilikan saham oleh pihak eksekutif atau pihak yang pelaksana aktivitas operasional perusahaan (Dewi dan Nugrahanti, 2014). Kepemilikan Institusional merupakan merupakan proporsi pemegang saham oleh institusi berbadan hukum, institusi keuangan, dana perwalian, dan institusi lainnya (Sembiring, 2017). 


\subsection{Penelitian Terdahulu}

Penelitian ini mengaitkan pengungkapan CSR dan manajemen laba. Beberapa penelitan membahas pengaruh pengungkapan CSR terhadap manjemen laba dengan beberapa variabel moderasi. Penelitian Ricardo dan Faisal (2015) yang dilakukan pada perusahaan yang terdaftar di Bursa Efek Indonesia (BEI) tahun 2013, menunjukkan bahwa pengungkapan CSR berpengaruh negatif terhadap manajemen laba, ukuran perusahaan tidak dapat memoderasi pengaruh pengungkapan CSR terhadap manajemen laba, profitabilitas dapat memoderasi pengaruh pengungkapan CSR terhadap manajemen laba, dan leverage tidak dapat memoderasi pengaruh CSR terhadap manajemen laba. Penelitian Sembiring (2017) yang dilakukan pada perusahaan pertambangan yang terdaftar di BEI periode 2010-2014, menyatakan bahwa terdapat pengaruh negatif antara tingkat pengungkapan CSR dengan perilaku manajemen laba yang dilakukan oleh manajemen, dewan komisaris independen mampu memperkuat hubungan negatif antara pengungkapan CSR dan manajemen laba, dan kepemilikan institusional mampu memperkuat hubungan negatif antara pengungkapan CSR dan manajemen laba. Penelitian Ardiani dan Sudana (2018) yang dilakukan pada perusahaan high profile yang terdaftar di BEI tahun 2014-2016, menunjukkan bahwa pengungkapan CSR berpengaruh negatif terhadap manajemen laba, kepemilikan institusional dapat memoderasi hubungan antara pengungkapan CSR dan manajemen laba, serta kepemilikan manajerial tidak dapat memoderasi hubungan antara pengungkapan CSR dan manajemen laba. Penelitian Buertey, dkk. (2019) yang dilakukan pada perusahaan Institusi non-finansial pada Johannesburg Stock Exchange dari 5 industri utama: consumer goods, consumer services, basic materials, industries, and technology/telecoms tahun 2012-2015, menyatakan bahwa terdapat hubungan positif antara board size dan CSR, terdapat hubungan positif antara instituional ownership dan CSR, terdapat hubungan positif antara block ownership dan CSR, terdapat hubungan positif antara CSR dan manajemen laba; board size dan block ownership dapat memoderasi hubungan CSR dan manajemen laba; board independence dan institutional ownership tidak dapat memoderasi hubungan CSR dan manajemen laba. Dari penelitian di atas menunjukkan ketidakkonsistenan hasil penelitian pengungkapan CSR terhadap manajemen CSR serta manajemen laba yang dibahas yaitu manajemen laba akrual, sedangkan akhir-akhir ini terdapat isu bahwa manajer lebih menyukai manajemen laba melalui manipulasi aktivitas riil dibanding manajemen laba melalui akrual.

\subsection{Pengembangan Hipotesis}

\subsubsection{Pengaruh Pengungkapan CSR terhadap Manajemen Laba Riil}

Perusahaan melakukan aktivitas-aktivitas yang berhubungan dengan tanggung jawab sosial sebagai bentuk kepedulian perusahaan terhadap lingkungan sosial di sekitarnya. Sebagai bentuk pertanggungjawaban atas kegiatan perusahaan yang berhubungan dengan CSR, perusahaan melakukan pengungkapan CSR dalam laporan 
tahunannya. Semakin luas perusahaan melakukan pengungkapan informasi yang berkaitan dengan aktivitas dan kondisi perusahaan menunjukkan perusahaan lebih terbuka dan transparan terhadap para pengguna laporan keuangan sehingga hal ini akan menurunkan kemungkinan terjadinya praktik manajemen laba, termasuk manajemen laba riil melalui aktivitas operasional perusahaan sehari-hari. Sebaliknya, perusahaan yang cenderung menutup-nutupi informasi dan kondisi sebenarnya mengenai perusahaan akan meningkatkan peluang bagi manajemen untuk melakukan manajemen laba (Sembiring, 2017). Hal ini dikarenakan adanya kesenjangan atau asimetri informasi antara pemegang saham dan manajer di mana pemegang saham memiliki akses yang terbatas terhadap kondisi perusahaan yang sebenarnya, sehingga hal ini akan menyebabkan timbulnya masalah keagenan.

Manajemen laba sebagai suatu upaya untuk merekayasa angka laba dianggap sebagai perilaku yang bertentangan dengan etika bisnis, sedangkan pengungkapan CSR merupakan bentuk komitmen perusahaan yang menunjukkan bahwa perusahaan beretika dan memiliki kepedulian terhadap lingkungan sekitar dan tidak hanya berfokus pada angka-angka dalam laporan keuangan. Perusahaan yang melakukan kegiatan tanggung jawab sosial dan melakukan pengungkapan CSR menunjukkan adanya transparansi sehingga mengurangi incentive manajer untuk melakukan tindakan oportunistik yaitu manajemen laba yang justru dapat merusak komitmen yang telah dibangun perusahaan (Sembiring, 2017). Perusahaan yang melakukan CSR dan pengungkapan CSR menunjukkan bahwa perusahaan memiliki fokus terhadap kelangsungan lingkungan hidup dan hubungannya dengan para pemangku kepentingan di masa mendatang. Perusahaan yang telah berkomitmen untuk melakukan praktik CSR akan berperilaku etis dan akan mengurangi praktik manajemen laba (Ricardo dan Faisal, 2015). Perusahaan yang memiliki etika dan rasa peduli dengan melakukan tanggung jawab sosial akan melakukan pengungkapan CSR lebih banyak untuk mengurangi asimetri informasi dan cenderung untuk melaporkan kinerja keuangan perusahaan dengan transparan sehingga tidak terdapat praktik manajemen laba yang mengindikasikan bahwa laporan keuangan perusahaan memiliki kredibilitas yang tinggi (Sembiring, 2017). Berdasarkan uraian di atas, maka dapat dirumuskan hipotesis sebagai berikut.

H1: Pengungkapan CSR berpengaruh negatif terhadap manajemen laba riil

2.8.2. Pengaruh Pengungkapan CSR terhadap Manajemen Laba Riil dengan Kepemilikan Manajerial sebagai Pemoderasi

Kepemilikan manajerial menunjukkan proporsi kepemilikan saham oleh manajemen (Ardiani dan Sudana, 2018). Apabila manajemen memiliki kepemilikan saham dalam perusahaan maka manajer akan bertindak lebih berhati-hati dalam melakukan pengambilan keputusan bisnis. Manajer akan merasakan manfaat jika keputusan bisns tersebut menghasilkan keuntungan yang optimal. Keputusan bisnis ini termasuk keputusan untuk kebijakan penjualan, potongan harga, syarat kredit, 
penentuan biaya-biaya, serta kebijakan mengenai produksi di mana manajemen dapat memanfaatkan keputusan bisnis ini untuk melakukan manajemen laba riil. Oleh karena itu manajer akan bekerja lebih baik dan optimal jika ia memiliki presentase kepemilikan saham dalam perusahaan (Ardiani dan Sudana, 2018).

Adanya kepemilikan saham oleh manajemen juga dapat menyelaraskan kepentingan antara pemegang saham dan manajer. Apabila kepentingan manajer dan pemegang saham dapat diselaraskan maka manajemen tidak akan termotivasi untuk merekayasa atau memanipulasi informasi yang dilaporkan dalam laporan keuangan sehingga kesenjangan informasi antara pemegang saham dan manajer juga akan berkurang. Manajemen juga akan mengungkapan informasi mengenai aktivitas dan kondisi perusahaan secara transparan, termasuk pengungkapan CSR serta informasi laba. Apabila perusahaan mampu memiliki transparansi yang baik mengenai informasi yang dilaporkan, maka kemungkinan manajemen melakukan manajemen laba juga kecil, termasuk manajemen laba riil yang berkaitan dengan keputusan bisnis seharihari. Berdasarkan uraian di atas, maka dapat dirumuskan hipotesis sebagai berikut.

H2: Kepemilikan manajerial memperkuat pengaruh negatif antara pengungkapan CSR dan manajemen laba riil.

2.8.3. Pengaruh Pengungkapan Corporate Social Responsibilty (CSR) terhadap Manajemen Laba Riil dengan Kepemilikan Institusional sebagai Pemoderasi

Kepemilikan institusional menunjukkan adanya kepemilikan saham oleh pemegang saham institusi. Kepemilikan institusional dapat mengurangi insentif manajer untuk melakukan tindakan oportunistik karena adanya pengawasan yang intens terhadap kinerja manajemen. Pemegang saham institusi mampu memonitoring manajemen secara efektif sehingga menurunkan kemungkinan terjadinya tindakan yang menyimpang ataupun tindakan oportunistik oleh manajemen. Pemegang saham institusi memiliki voting power sehingga berpengaruh terhadap keputusan perusahaan dan dapat mengurangi asimetri informasi antara pemegang saham dan manajer (Sembiring, 2017).

Perusahaan yang fungsi pengelolaan dan kepemilikan sahamnya terpisah dapat menimbulkan masalah keagenan. Dengan adanya kepemilikan institusional maka fungsi pengawasan terhadap manajemen akan lebih baik. Kepemilikan institusional dapat menjadi mekanisme yang efektif untuk memonitoring manajemen sehingga kemungkinan terjadinya manajamen laba, termasuk manajemen laba riil yang dilakukan selama kegiatan operasional sehari-hari dapat dikurangi (Ardiani dan Sudana, 2018). Mengingat tanggung jawab sosial dapat memberikan kontribusi positif bagi perusahaan maka pemegang saham lebih menginginkan pihak manajemen untuk melakukan tanggung jawab sosial sehingga kemakmuran pemegang saham akan tetap terjamin. Selain itu manajemen juga akan berfokus terhadap peningkatan kinerja perusahaan serta akan mengungkapkan informasi-informasi keuangan perusahaan secara transparan mengingat adanya pengawasan yang efektif dari pemegang saham 


\section{Buana Akuntansi}

terhadap manajemen. Hal akan menurunkan kemungkinan dilakukannya praktik manajemen laba riil oleh perusahaan. Berdasarkan uraian di atas, maka dapat dirumuskan hipotesis sebagai berikut.

H3: Kepemilikan institusional memperkuat pengaruh negatif antara pengungkapan CSR dan manajemen laba riil.

\section{Metodologi Penelitian}

3.1. Teknik Pengambilan Sampel

Populasi penelitian adalah perusahaan manufaktur yang terdaftar di BEI. Dari populasi tersebut diambil sampel sebagai berikut dengan menggunakan metode purposive sampling dengan kriteria sebagai berikut:

Tabel 3.1. Kriteria Pemilihan Sampel

\begin{tabular}{lc}
\hline \multicolumn{1}{c}{ Keterangan } & $\begin{array}{c}\text { Jumlah } \\
\text { Perusahaan }\end{array}$ \\
\hline Populasi: Perusahaan manufaktur di BEI & 169 \\
\hline $\begin{array}{l}\text { Perusahaan manufaktur yang tidak memenuhi } \\
\text { kriteria: }\end{array}$ & $(11)$ \\
1. Perusahaan manufaktur yang terdaftar di Bursa \\
Efek Indonesia dari tahun 2016-2019 secara \\
berturut-turut \\
2. Laporan tahunan perusahaan tersedia di website \\
$\begin{array}{l}\text { BEI atau website perusahaan secara lengkap } \\
\text { periode 2016-2019 }\end{array}$ \\
3. Perusahaan manufaktur di BEI yang \\
menerbitkan laporan tahunan secara lengkap \\
termasuk terdapatnya informasi mengenai \\
kepemilikan saham di dalam perusahaan \\
tersebut
\end{tabular}

Sumber: idx.co.id (diolah) 


\subsection{Operasional Variabel Penelitian}

\subsubsection{Manajemen Laba Riil}

Manajemen laba riil merupakan pemanipulasian atau perekayasaan angka laba yang dapat dilakukan selama periode berjalan melalui kegiatan operasional sehari-hari perusahaan (Majid, dkk., 2020). Dalam penelitian ini proksi yang digunakan untuk manajemen laba riil dibagi menjadi tiga Roychowdhury (2006) dan diukur dengan langkah-langkah sebagai berikut.

1. Arus Kas Operasi Normal. Model Regresi Arus Kas Operasi Normal yaitu:

$$
\mathrm{CFO}_{\mathrm{t}} / \mathrm{A}_{\mathrm{t}-1}=\alpha_{0}+\alpha_{1}\left(1 / \mathrm{A}_{\mathrm{t}-1}\right)+\alpha_{2}\left(\mathrm{~S}_{\mathrm{t}} / \mathrm{A}_{\mathrm{t}-1}\right)+\alpha_{3}\left(\Delta \mathrm{S}_{\mathrm{t}} / \mathrm{A}_{\mathrm{t}-1}\right)+\varepsilon
$$

2. Biaya Produksi Normal.Model Regresi Biaya Produksi Normal yaitu:

$$
\text { PRODt/A } \mathrm{t}_{-1}=\alpha_{0}+\alpha_{1}\left(1 / \mathrm{A}_{\mathrm{t}-1}\right)+\alpha_{2}\left(\mathrm{~S}_{\mathrm{t}} / \mathrm{A}_{\mathrm{t}-1}\right)+\alpha_{3}\left(\Delta \mathrm{S}_{\mathrm{t}} / \mathrm{A}_{\mathrm{t}-1}\right)+\alpha_{4}\left(\Delta \mathrm{S}_{\mathrm{t}-}\right.
$$

3. Biaya Diskresioner Normal (Reduction of Discretionary Expenditures). Model regresi biaya diskresioner normal yaitu:

$$
\text { DISEXP } / A_{t-1}=\alpha_{0}+\alpha_{1}\left(1 / A_{t-1}\right)+\alpha_{2}\left(S_{t} / A_{t-1}\right)+\varepsilon_{t}
$$

Keterangan:

$\begin{array}{ll}\mathrm{CFO}_{\mathrm{t}} & =\text { Arus kas operasi perusahaan i pada tahun } \mathrm{t} \\ \text { PRODt } & =\text { Biaya produksi tahun } \mathrm{t} \text { (COGS }+\Delta \mathrm{inv}) \\ \text { DISEXP }_{\mathrm{t}} & =\text { Biaya diskresioner (biaya iklan, biaya R\&D, biaya penjualan, serta biaya } \\ & =\text { administrasi umum) perusahaan i pada tahun } \mathrm{t} \\ \mathrm{A}_{\mathrm{t}-1} & =\text { Total aset perusahaan i pada tahun } \mathrm{t} \\ \mathrm{S}_{\mathrm{t}} & =\text { Penjualan perusahaan i pada tahun } \mathrm{t} \\ \Delta S_{\mathrm{t}} & =\text { Penjualan perusahaan i pada tahun } \mathrm{t} \text { dikurangi dengan tahun } \mathrm{t}-1 \\ \Delta S_{\mathrm{t}-1} & =\text { Koefisien regresi } \\ \mathrm{a} & =\text { error term pada tahun } \mathrm{t}\end{array}$

Dalam penelitian ini proksi yang digunakan adalah arus kas operasi abnormal (ABCFO), produksi abnormal (ABNPROD), dan biaya diskresioner abnormal (ABNDE). Nilai abnormal tersebut adalah nilai residual dari estimasi model regresi di atas. Nilai residual tersebut diperoleh dengan mengurangkan nilai aktual arus kas kegiatan operasi, biaya diskresioner dan biaya produksi yang diskalakan dengan total aktiva satu tahun sebelum periode pengujian dengan arus kas kegiatan operasi, biaya diskresioner dan biaya produksi normal yang dihitung dengan menggunakan koefisien estimasi dari model persamaan di atas.

3.2.2. Pengungkapan Corporate Social Responsibility (CSR)

Corporate Social Responsibility (CSR) merupakan bentuk komitmen dan tanggung jawab perusahaan terhadap lingkungan sosial di sekitarnya (Ricardo dan Faisal, 2015). Dalam penelitian ini pengungkapan CSR mengacu pada instrumen Global Reporting Initiatve (GRI) G4. GRI G4 terdiri dari 91 item pengungkapan yang dibagi menjadi tiga 


\section{Buana Akuntansi}

kategori yaitu ekonomi, lingkungan, dan sosial. Kategori ini dibagi menjadi 91 item dengan rincian yaitu (Sembiring, 2017) kategori ekonomi terdiri dari 4 aspek dan 9 indikator, kategori lingkungan teridri dari 12 aspek dan 34 indikator, dan kategori sosial terdiri dari 30 aspek dan 48 indikator. Pengukuran pengungkapan CSR menggunakan pendekatan dikotomis, yaitu jika item diungkapkan akan diberi nilai satu (1) dan jika tidak diungkapkan maka akan diberi nilai nol (0). Kemudian skor ditambahkan dan dibagi dengan skor keseluruhan. Pengukuran pengungkapan CSR ini dapat dirumuskan sebagai berikut.

\subsubsection{Kepemilikan Manajerial}

Kepemilikan manajerial merupakan jumlah kepemilkan saham oleh manajemen perusahaan (Ardiana dan Sudana, 2018). Menurut Subiantoro dan Mildawati (2015) kepemilikan manajerial dapat dirumuskan sebagai berikut:

\subsubsection{Kepemilikan Institusional}

$$
\text { Kepemilikan Manajerial }=\frac{\text { Proporsi saham yang dimiliki manajemen }}{\text { Jumlah saham beredar }}
$$

Kepemilikan institusional merupakan kepemilikan saham oleh pihak institusi. Pemegang saham institusi berperan untuk melakukan pengawasan yang efektif terhadap kinerja manajemen. Kepemilikan institusional dapat diukur menggunakan rumus sebagai berikut:

$$
\text { Kepemilikan Institusional }=\frac{\text { Proporsi saham yang dimiliki institusi }}{\text { Jumlah saham beredar }}
$$

3.3. Teknik Analisis Data

Penelitian ini menggunakan analisis regresi linear berganda dan regresi linear moderasi. Persamaan model regresi dalam penelitian ini yaitu:

Pers. 1a: $\mathrm{ABNCFO}=\alpha+\beta 1 \mathrm{CSR}+\beta 2 \mathrm{KM}+\beta 3 \mathrm{KI}+\varepsilon$

Pers. 1b: $\mathrm{ABNCFO}=\alpha+\beta 1 \mathrm{CSR}+\beta 2 \mathrm{KM}+\beta 3 \mathrm{KI}+\beta 4 \mathrm{CSR}^{*} \mathrm{KM}+\beta 5 \mathrm{CSR}{ }^{*} \mathrm{KI}+\varepsilon$

Pers. 2a: ABNPROD $\quad=\alpha+\beta 1 C S R+\beta 2 \mathrm{KM}+\beta 3 \mathrm{KI}+\varepsilon$

Pers. 2b: ABNPROD $=a+\beta 1 \mathrm{CSR}+\beta 2 \mathrm{KM}+\beta 3 \mathrm{KI}+\beta 4 \mathrm{CSR}^{*} \mathrm{KM}+\beta 5 \mathrm{CSR}^{*} \mathrm{KI}+\varepsilon$

Pers. 3a: ABNDE $=\alpha+\beta 1 C S R+\beta 2 \mathrm{KM}+\beta 3 \mathrm{KI}+\varepsilon$

Pers. 3b: ABNDE $=\alpha+\beta 1 \mathrm{CSR}+\beta 2 \mathrm{KM}+\beta 3 \mathrm{KI}+\beta 4 \mathrm{CSR}^{*} \mathrm{KM}+\beta 5 \mathrm{CSR}^{*} \mathrm{KI}+\varepsilon$

Keterangan:

$\mathrm{ABNCFO}=$ Arus kas operasi abnormal

$\mathrm{ABNPROD}=$ Biaya produksi abnormal

$\mathrm{ABNDE} \quad=$ Biaya diskresioner abnormal

CSR = Pengungkapan CSR

KM = Kepemilikan Manajerial

KI $=$ Kepemilikan Institusional

$\mathrm{a}=$ Konstanta

$\beta \quad=$ Koefisien regresi

$\varepsilon \quad=$ Kesalahan

12|Jurnal Buana Akuntasi 


\section{Buana Akuntansi}

\section{Analisis dan Pembahasan}

4.1. Statistik Deskriptif

Statistik desktriptif setiap variabel disajikan dalam table 4.1 berikut:

Tabel 4.1. Statistik Deskriptif

\begin{tabular}{cccccc}
\hline & N & Minimum & Maximum & Mean & $\begin{array}{c}\text { Std. } \\
\text { Deviation }\end{array}$ \\
\hline ABNCFO & 182 & $-0,2844012$ & 0,4480161 & 0,0077081 & 0,1159510 \\
\hline ABNPROD & 182 & $-0,6813038$ & 0,5469126 & 0,0010680 & 0,2066106 \\
\hline ABNDE & 182 & $-0,2555982$ & 0,4721770 & $-0,0062222$ & 0,1263166 \\
\hline CSR & 182 & 0,0769231 & 0,2527473 & 0,1851226 & 0,0410171 \\
\hline KM & 182 & 0,0000000 & 0,8100000 & 0,0386594 & 0,1109506 \\
\hline KI & 182 & 0,0000000 & 1,0000000 & 0,7244654 & 0,1740734 \\
\hline $\begin{array}{c}\text { Valid N } \\
\text { (listwise) }\end{array}$ & 182 & & & & \\
\hline
\end{tabular}

Berdasarkan table di atas Nilai rata-rata dari arus kas operasi abnormal yaitu sebesar 0,0077081 dan standar deviasi sebesar 0,1159510. Nilai rata-rata dari biaya produksi abnormal yaitu sebesar 0,0010680 dan standar deviasi sebesar 0,2066106. Nilai rata-rata dari biaya diskresioner abnormal yaitu sebesar $-0,0062222$ dan standar deviasi sebesar 0,1263166. Nilai rata-rata dari pengungkapan CSR yaitu sebesar 0,1851226 yang artinya bahwa perusahaan hanya mengungkapkan sebanyak $18,5 \%$ dari 91 item pengungkapan serta standar deviasi sebesar 0,0410171/ Nilai rata-rata dari kepemilikan manjerial cukup rendah yaitu sebesar 0,0386594 dan standar deviasi sebesar 0,1109506. Nilai rata-rata dari kepemilikan institusional cukup tinggi yaitu sebesar 0,7244654 dan standar deviasi sebesar 0,1740734. Variasi data dalam penelitian ini rendah karena standar deviasi mendekati nilai nol.

\subsection{Uji Asumsi Klasik}

4.2.1. Uji Normalitas

Pengujian normalitas residual data dalam penelitian ini menggunakan one sample Kolmogorov-Smirnow test (K-S). Berikut ini merupakan tabel hasil uji normalitas atas data residual dalam penelitian untuk setiap proksi variabel manajemen laba riil.

Tabel 4.2 Hasil Uji Normalitas Variabel Dependen Manajemen Laba Riil

\begin{tabular}{cccc}
\hline Persamaan & $\begin{array}{c}\text { Monte Carlo Sig } \\
\text { (2- } \\
\text { tailed) Sig }\end{array}$ & $\begin{array}{c}\text { Monte Carlo Sig } \\
\mathbf{( 2 -} \\
\text { tailed) Upper } \\
\text { Bound }\end{array}$ & Keterangan \\
\hline $1 \mathrm{a}$ & 0,066 & 0,102 & $\begin{array}{c}\text { Data terdistribusi } \\
\text { normal }\end{array}$ \\
\hline $1 \mathrm{~b}$ & 0,115 & 0,162 & $\begin{array}{c}\text { Data terdistribusi } \\
\text { normal }\end{array}$ \\
\hline
\end{tabular}




\section{Buana Akuntansi}

\begin{tabular}{cccc}
\hline $2 \mathrm{a}$ & 0,005 & 0,016 & $\begin{array}{c}\text { Data tidak } \\
\text { terdistribusi normal }\end{array}$ \\
\hline $2 \mathrm{~b}$ & 0,077 & 0,116 & $\begin{array}{c}\text { Data terdistribusi } \\
\text { normal }\end{array}$ \\
\hline $3 \mathrm{a}$ & 0,000 & 0,016 & $\begin{array}{c}\text { Data tidak } \\
\text { terdistribusi normal }\end{array}$ \\
\hline $3 \mathrm{~b}$ & 0,000 & 0,016 & $\begin{array}{c}\text { Data tidak } \\
\text { terdistribusi normal }\end{array}$ \\
\hline
\end{tabular}

Menurut Ajija, dkk (2011:42; dalam Akbary, 2017), uji normalitas digunakan apabila data dalam penelitian berjumlah kurang dari 30 untuk menguji apakah residual terdistribusi normal. Jika jumlah data dalam penelitan lebih dari 30, maka tidak perlu dilakukan uji normalitas karena distribusi sampling residual mendekati normal. Pada penelitian ini menggunakan data berjumlah 182 sehingga uji normalitas dapat dianggap lolos uji.

\subsubsection{Uji Multikolinearitas}

Uji multikolinieritas bertujuan untuk menguji apakah dalam model regresi terdapat hubungan korelasi yang tinggi atau sempurna di antara variabel independen. Berikut ini merupakan tabel hasil uji multikolinearitas.

Tabel 4.3 Hasil Uji Multikolinieritas

\begin{tabular}{|c|c|c|c|c|}
\hline Persamaan & $\begin{array}{c}\text { Variabel } \\
\text { Independen }\end{array}$ & Tolerance & VIF & Keterangan \\
\hline \multirow{3}{*}{$1 \mathrm{a}$} & CSR & 0,997 & 1,003 & $\begin{array}{c}\text { Bebas } \\
\text { multikolinieritas }\end{array}$ \\
\hline & KM & 0,698 & 1,432 & $\begin{array}{c}\text { Bebas } \\
\text { multikolinieritas }\end{array}$ \\
\hline & KI & 0,698 & 1,432 & $\begin{array}{c}\text { Bebas } \\
\text { multikolinieritas }\end{array}$ \\
\hline \multirow{3}{*}{$2 a$} & CSR & 0,997 & 1,003 & $\begin{array}{c}\text { Bebas } \\
\text { multikolinieritas }\end{array}$ \\
\hline & KM & 0,698 & 1,432 & $\begin{array}{c}\text { Bebas } \\
\text { multikolinieritas }\end{array}$ \\
\hline & KI & 0,698 & 1,432 & $\begin{array}{c}\text { Bebas } \\
\text { multikolinieritas }\end{array}$ \\
\hline \multirow{3}{*}{$3 a$} & CSR & 0,997 & 1,003 & $\begin{array}{c}\text { Bebas } \\
\text { multikolinieritas }\end{array}$ \\
\hline & KM & 0,698 & 1,432 & $\begin{array}{c}\text { Bebas } \\
\text { multikolinieritas }\end{array}$ \\
\hline & KI & 0,698 & 1,432 & $\begin{array}{l}\text { Bebas } \\
\text { multikolinieritas }\end{array}$ \\
\hline
\end{tabular}




\section{Buana Akuntansi}

Berdasarkan tabel di atas nilai tolerance untuk variabel CSR, KM, dan KI menunjukkan nilai lebih besar dari 0,1 dan nilai VIF untuk variabel CSR, KM, dan KI menunjukkan nilai lebih kecil dari 10, sehingga dapat disimpulkan bahwa ketiga variabel ini bebas dari multikolinieritas.

\subsubsection{Uji Heteroskedastisitas}

Dalam penelitian ini uji heteroskedastisitas dilakukan dengan uji glejser. Berikut ini merupakan tabel hasil uji heteroskedastisitas.

Tabel 4.4 Hasil Uji Heteroskedastisitas

\begin{tabular}{ccc}
\hline Modal Persamaan & Signifikansi & Kesimpulan \\
\hline $1 \mathrm{a}$ & 0,000 & $\begin{array}{c}\text { Terjadi } \\
\text { heteroskedastisitas }\end{array}$ \\
\hline $1 \mathrm{~b}$ & 0,000 & $\begin{array}{c}\text { Terjadi } \\
\text { heteroskedastisitas }\end{array}$ \\
\hline $2 \mathrm{a}$ & 0,004 & $\begin{array}{c}\text { Terjadi } \\
\text { heteroskedastisitas }\end{array}$ \\
\hline $2 \mathrm{~b}$ & 0,059 & $\begin{array}{c}\text { Bebas } \\
\text { heteroskedastisitas }\end{array}$ \\
\hline $3 \mathrm{a}$ & 0,002 & $\begin{array}{c}\text { Terjadi } \\
\text { heteroskedastisitas }\end{array}$ \\
\hline $3 \mathrm{~b}$ & 0,013 & $\begin{array}{c}\text { Terjadi } \\
\text { heteroskedastisitas }\end{array}$
\end{tabular}

Pada penelitian ini menggunakan data panel sehingga tidak harus dilakukan pengujian asumsi klasik (Gujarati, 2012:237) sehingga uji heteroskedastisitas ini dapat diabaikan dan diasumsikan lolos uji.

4.2.4. Uji Autokorelasi

Dalam penelitian ini untuk mendeteksi terjadinya autokorelasi digunakan uji DurbinWatson (DW test). Berikut ini merupakan tabel hasil uji autokorelasi.

Tabel 4.5 Hasil Uji Autokorelasi

\begin{tabular}{ccccc}
\hline $\begin{array}{c}\text { Modal } \\
\text { Persamaan }\end{array}$ & $\mathbf{d u}$ & $\mathbf{d}$ & $\mathbf{4 - d u}$ & Keterangan \\
\hline 1a & 1.8025 & 1,037 & 2,1975 & Terjadi autokorelasi \\
\hline 1b & 1.8025 & 1,052 & 2,1975 & Terjadi autokorelasi \\
\hline 2a & 1.8025 & 0,647 & 2,1975 & Terjadi autokorelasi \\
\hline 2b & 1.8025 & 0,623 & 2,1975 & Terjadi autokorelasi \\
\hline 3a & 1.8025 & 0,494 & 2,1975 & Terjadi autokorelasi \\
\hline 3b & 1.8025 & 0,499 & 2,1975 & Terjadi autokorelasi \\
\hline
\end{tabular}

Pada penelitian ini menggunakan data panel sehingga tidak harus dilakukan pengujian asumsi klasik (Gujarati, 2012:237) sehingga uji autokorelasi ini dapat diabaikan dan diasumsikan lolos uji. 


\section{Buana Akuntansi}

DEBBY KURNIAWATI

Vol. 6 No. 2

ISSN 2528-1119

E-ISSN 2580-5452

4.3. Uji Kelayakan Model

4.3.1. Uji F

Uji F digunakan untuk menguji kelayakan suatu model regresi. Berikut ini merupakan tabel hasil uji F.

Tabel 4.6 Hasil Uji F

\begin{tabular}{cccc}
\hline $\begin{array}{c}\text { Model } \\
\text { Persamaan }\end{array}$ & F & Signifikansi & Keterangan \\
\hline $1 \mathrm{a}$ & 4,929 & 0,003 & Model layak \\
\hline $1 \mathrm{~b}$ & 4,028 & 0,002 & Model layak \\
\hline $2 \mathrm{a}$ & 6,683 & 0,000 & Model layak \\
\hline $2 \mathrm{~b}$ & 4,956 & 0,000 & Model layak \\
\hline 3a & 3,446 & 0,018 & Model layak \\
\hline 3b & 2,289 & 0,048 & Model layak \\
\hline
\end{tabular}

Berdasarkan tabel di atas, nilai signifikansi yang diperoleh dari 6 model persamaan yaitu di bawah 0,05. Dengan demikian menyatakan bahwa model regresi layak atau fit untuk menguji pengaruh variabel independen (pengungkapan CSR) terhadap variabel dependen (manajamen laba riil yang diproksikan dengan arus kas operasi abnormal, biaya produksi abnormal, dan biaya diskresioner abnormal) dengan variabel moderasi kepemilikan manajerial dan kepemilikan institusional.

\subsubsection{Uji Koefisien Determinasi}

Berikut ini merupakan tabel hasil uji koefisien determinasi.

Tabel 4.7 Hasil Uji Koefisien Determinasi

\begin{tabular}{ccc}
\hline $\begin{array}{c}\text { Model } \\
\text { Persamaan }\end{array}$ & $\begin{array}{c}\text { Adjusted } \boldsymbol{R} \\
\text { Square }\end{array}$ & Keterangan \\
\hline $1 \mathrm{a}$ & 0,061 & Tanpa moderasi \\
\hline $1 \mathrm{~b}$ & 0,077 & $\begin{array}{c}\text { Moderasi kepemilikan manajerial } \\
\text { dan kepemilikan institusional }\end{array}$ \\
\hline $2 \mathrm{a}$ & 0,086 & Tanpa moderasi \\
\hline $2 \mathrm{~b}$ & 0,099 & $\begin{array}{c}\text { Moderasi kepemilikan manajerial } \\
\text { dan kepemilikan institusional }\end{array}$ \\
\hline $3 \mathrm{a}$ & 0,039 & Tanpa moderasi \\
\hline $3 \mathrm{~b}$ & 0,034 & $\begin{array}{c}\text { Moderasi kepemilikan manajerial } \\
\text { dan kepemilikan institusional }\end{array}$ \\
\hline
\end{tabular}

Pada persamaan 1a menunjukkan nilai adjusted $R$ square sebesar 0,061 yang artinya kemampuan variabel independen (pengungkapan CSR) dalam mempengaruhi variabel dependen (arus kas operasi abnormal) yaitu sebesar 0,061. Pengujian pada persamaan $1 \mathrm{~b}$ menunjukkan bahwa nilai adjusted $R$ square sebesar 0,077 di mana 


\section{Buana Akuntansi}

mengalami kenaikan jika dibanding adjusted $R$ square pada persamaan 1a, yang artinya variabel moderasi (kepemilikan manajerial dan kepemilikan institusional) memperkuat hubungan variabel independen (pengungkapan CSR) terhadap variabel dependen (arus kas operasi abnormal).

Pada persamaan 2a menunjukkan nilai adjusted $R$ square sebesar 0,086 yang artinya kemampuan variabel independen (pengungkapan CSR) dalam mempengaruhi variabel dependen (biaya produksi abnormal) yaitu sebesar 0,086. Pengujian pada persamaan $2 \mathrm{~b}$ menunjukkan bahwa nilai adjusted $R$ square sebesar 0,099 di mana mengalami kenaikan jika dibanding adjusted $R$ square pada persamaan $2 \mathrm{a}$, yang artinya variabel moderasi (kepemilikan manajerial dan kepemilikan institusional) memperkuat hubungan variabel independen (pengungkapan CSR) terhadap variabel dependen (biaya produksi abnormal).

Pada persamaan 3a menunjukkan nilai adjusted $R$ square sebesar 0,039 yang artinya kemampuan variabel independen (pengungkapan CSR) dalam mempengaruhi variabel dependen (biaya diskresioner abnormal) yaitu sebesar 0,039. Pengujian pada persamaan $3 \mathrm{~b}$ menunjukkan bahwa nilai adjusted $R$ square sebesar 0,034 di mana mengalami penurunan jika dibanding adjusted $R$ square pada persamaan $3 a$, yang artinya variabel moderasi (kepemilikan manajerial dan kepemilikan institusional) tidak dapat memperkuat pengaruh variabel independen (pengungkapan CSR) terhadap variabel dependen (biaya diskresioner abnormal).

\subsection{Uji Hipotesis}

Uji hipotesis pada penelitian ini dilakukan untuk menguji apakah variabel independen berpengaruh secara signifikan terhadap variabel dependen serta seberapa jauh pengaruh variabel independen terhadap variabel dependen. Berikut merupakan tabel hasil pengujian hipotesis.

\begin{tabular}{cccccc}
\multicolumn{5}{c}{ Tabel 4.8 Hasil Uji t Persamaan 1a } \\
\cline { 1 - 4 } Variabel & $\begin{array}{l}\text { Unstandardized } \\
\text { Coef. }\end{array}$ & $\mathbf{t}$ & Sig. & Keterangan \\
\cline { 2 - 5 } & $\mathrm{B}$ & Std. Error & & & \\
\cline { 1 - 4 } $\begin{array}{c}\text { (Constant } \\
\text { ) }\end{array}$ & $-0,216$ & 0,060 & $-3,630$ & 0,000 & \\
\hline CSR & 0,609 & 0,204 & 2,986 & 0,003 & Berpengaruh positif \\
\hline KM & 0,128 & 0,090 & 1,427 & 0,155 & Tidak berpengaruh \\
\hline KI & 0,147 & 0,057 & 2,559 & 0,011 & Berpengaruh positif \\
\hline
\end{tabular}

Persamaan regresi yang terbentuk adalah sebagai berikut:

$$
\mathrm{ABNCFO}=-0,216+0,609 \mathrm{CSR}+0,128 \mathrm{KM}+0,147 \mathrm{KI}+\varepsilon
$$

Variabel CSR memperoleh nilai t sebesar 2,986 dan signifikansi sebesar 0,003 yang artinya nilai signifikansi tersebut lebih kecil dari 0,05. Dengan demikian dapat disimpulkan bahwa variabel CSR berpengaruh positif signifikan terhadap ABNCFO. Semakin besar nilai CSR maka semakin besar juga nilai ABNCFO. Manajemen laba riil 
diindikasikan dengan rendahnya nilai ABNCFO (bernilai negatif). Dari hasil uji t dapat disimpulkan bahwa semakin tinggi nilai CSR maka semakin rendah manajemen laba riil melalui arus kas operasi abnormal (semakin bernilai cpositif), sehingga $\mathrm{H} 1$ yang menyatakan bahwa pengungkapan CSR berpengaruh negatif terhadap manajemen laba riil (yang diproksikan dengan arus kas operasi abnormal) diterima. Variabel KM memperoleh nilai t sebesar 1,427 dan signifikansi sebesar 0,155. Dengan demikian dapat disimpulkan bahwa variabel KM tidak berpengaruh terhadap ABNCFO. Variabel KI memperoleh nilai t sebesar 2,559 dan signifikansi sebesar 0,011. Dengan demikian dapat disimpulkan bahwa variabel KI berpengaruh positif signifikan terhadap ABNCFO.

Tabel 4.9 Hasil Uji t Persamaan $1 b$

\begin{tabular}{cccccc}
\hline Variabel & \multicolumn{2}{l}{$\begin{array}{l}\text { Unstandardized } \\
\text { Coef. }\end{array}$} & $\mathbf{t}$ & Sig. & Keterangan \\
\cline { 2 - 4 } & $\mathrm{B}$ & Std. Error & & & \\
\hline $\begin{array}{c}\text { (Constant } \\
\text { ) }\end{array}$ & 0,013 & 0,193 & 0,067 & 0,946 & \\
\hline CSR & $-0,595$ & 0,978 & $-0,608$ & 0,544 & Tidak berpengaruh \\
\hline KM & 1,258 & 0,824 & 1,527 & 0,129 & Tidak berpengaruh \\
\hline KI & $-0,179$ & 0,250 & $-0,717$ & 0,475 & Tidak berpengaruh \\
\hline CSR*KM & $-6,129$ & 4,394 & $-1,395$ & 0,165 & Tidak berpengaruh \\
\hline CSR $^{*} \mathrm{KI}$ & 1,711 & 1,270 & 1,347 & 0,180 & Tidak berpengaruh \\
\hline
\end{tabular}

Persamaan regresi yang terbentuk adalah sebagai berikut:

$\mathrm{ABNCFO}=0,013-0,595 \mathrm{CSR}+1,258 \mathrm{KM}-0,179 \mathrm{KI}-6,129 \mathrm{CSR} * \mathrm{KM}+1,711 \mathrm{CSR} * \mathrm{KI}+\varepsilon$

Variabel CSR memperoleh nilai t sebesar -0,608 dan signifikansi sebesar 0,544. Dengan demikian dapat disimpulkan bahwa variabel CSR tidak berpengaruh terhadap ABNCFO, sehingga H1 yang menyatakan bahwa pengungkapan CSR berpengaruh negatif terhadap manajemen laba riil (yang diproksikan dengan arus kas operasi abnormal) ditolak. Variabel KM memperoleh nilai $t$ sebesar 1,527 dan signifikansi sebesar 0,129. Variabel KI memperoleh nilai t sebesar -0,717 dan signifikansi sebesar 0,475. Dengan demikian dapat disimpulkan bahwa variabel KM dan KI tidak berpengaruh terhadap ABNCFO. Variabel CSR*KM memperoleh nilai t sebesar -1,395 dan signifikansi sebesar 0,165. Dengan demikian dapat disimpulkan bahwa variabel CSR*KM tidak berpengaruh terhadap ABNCFO, sehingga $\mathrm{H} 2$ yang menyatakan bahwa kepemilikan manajerial memperkuat pengaruh negatif antara pengungkapan CSR dan manajemen laba riil (yang diproksikan dengan arus kas operasi abnormal) ditolak. Variabel CSR*KI memperoleh nilai $\mathrm{t}$ sebesar 1,347 dan signifikansi sebesar 0,180. Dengan demikian dapat disimpulkan bahwa variabel CSR ${ }^{*} \mathrm{KI}$ tidak berpengaruh terhadap ABNCFO, sehingga H3 yang menyatakan bahwa kepemilikan institusional memperkuat pengaruh negatif antara pengungkapan CSR dan manajemen laba riil (yang diproksikan dengan arus kas operasi abnormal) ditolak. 
Tabel 4.10 Hasil Uji t Persamaan 2a

\begin{tabular}{|c|c|c|c|c|c|}
\hline \multirow[t]{2}{*}{ Variabel } & \multicolumn{2}{|c|}{$\begin{array}{l}\text { Unstandardized } \\
\text { Coef. }\end{array}$} & \multirow[t]{2}{*}{$\mathbf{t}$} & \multirow[t]{2}{*}{ Sig. } & \multirow[t]{2}{*}{ Keterangan } \\
\hline & B & Std. Error & & & \\
\hline $\begin{array}{c}\text { (Constant } \\
\text { ) }\end{array}$ & 0,443 & 0,105 & 4,229 & 0,000 & \\
\hline CSR & $-1,387$ & 0,358 & $-3,869$ & 0,000 & Berpengaruh negatif \\
\hline KM & $-0,205$ & 0,158 & $-1,292$ & 0,198 & Tidak berpengaruh \\
\hline KI & $-0,245$ & 0,101 & $-2,428$ & 0,016 & Berpengaruh negatif \\
\hline
\end{tabular}

Persamaan regresi yang terbentuk adalah sebagai berikut:

$$
\text { ABNPROD }=0,443-1,387 \text { CSR - 0,205KM - 0,245KI }+\varepsilon
$$

Variabel CSR memperoleh nilai t sebesar -3,869 dan signifikansi sebesar 0,000. Dengan demikian dapat disimpulkan bahwa variabel CSR berpengaruh negatif signifikan terhadap ABNPROD. Semakin besar nilai CSR maka semakin kecil nilai ABNPROD. Manajemen laba riil diindikasikan dengan tingginya nilai ABNPROD. Dari hasil uji $\mathrm{t}$ dapat disimpulkan bahwa semakin tinggi nilai CSR maka semakin rendah manajemen laba riil melalui biaya produksi abnormal sehingga H1 yang menyatakan bahwa pengungkapan CSR berpengaruh negatif terhadap manajemen laba riil (yang diproksikan dengan biaya produksi abnormal) diterima. Variabel KM memperoleh nilai t sebesar -1,292 dan signifikansi sebesar 0,198. Dengan demikian dapat disimpulkan bahwa variabel KM tidak berpengaruh terhadap ABNPROD. Variabel KI memperoleh nilai $t$ sebesar -2,428 dan signifikansi sebesar 0,016. Dengan demikian dapat disimpulkan bahwa variabel KI berpengaruh negatif signifikan terhadap ABNPROD.

Tabel 4.11 Hasil Uji t Persamaan 2b

\begin{tabular}{cccccc}
\hline Variabel & \multicolumn{2}{l}{$\begin{array}{l}\text { Unstandardized } \\
\text { Coef. }\end{array}$} & $\mathbf{t}$ & Sig. & Keterangan \\
\cline { 2 - 4 } & $\mathrm{B}$ & Std. Error & & & \\
\hline $\begin{array}{c}\text { (Constant } \\
\text { ) }\end{array}$ & $-0,199$ & 0,340 & $-0,583$ & 0,560 & \\
\hline CSR & 1,959 & 1,723 & 1,137 & 0,257 & Tidak berpengaruh \\
\hline KM & $-0,278$ & 1,452 & $-0,191$ & 0,849 & Tidak berpengaruh \\
\hline KI & 0,619 & 0,440 & 1,405 & 0,162 & Tidak berpengaruh \\
\hline CSR $^{*}$ KM & 0,536 & 7,739 & 0,069 & 0,945 & Tidak berpengaruh \\
\hline CSR $^{*}$ KI & $-4,511$ & 2,236 & $-2,017$ & 0,045 & Berpengaruh negatif \\
\hline
\end{tabular}

Persamaan regresi yang terbentuk adalah sebagai berikut:

ABNPROD $=-0,199+1,959 \mathrm{CSR}-0,278 \mathrm{KM}+0,619 \mathrm{KI}+0,536 \mathrm{CSR}{ }^{*} \mathrm{KM}-4,511 \mathrm{CSR} * \mathrm{KI}+$

$\varepsilon$

Variabel CSR memperoleh nilai $\mathrm{t}$ sebesar 1,137 dan signifikansi sebesar 0,257. Dengan demikian dapat disimpulkan bahwa variabel CSR tidak berpengaruh terhadap 
ABNPROD, sehingga H1 yang menyatakan bahwa pengungkapan CSR berpengaruh negatif terhadap manajemen laba riil (yang diproksikan dengan biaya produksi abnormal) ditolak. Variabel KM memperoleh nilai $t$ sebesar -0,191 dan signifikansi sebesar 0,849. Variabel KI memperoleh nilai $\mathrm{t}$ sebesar 1,405 dan signifikansi sebesar 0,162. Dengan demikian dapat disimpulkan bahwa variabel KM dan KI tidak berpengaruh terhadap ABNPROD. Variabel CSR*KM memperoleh nilai t sebesar 0,069 dan signifikansi sebesar 0,945. Dengan demikian dapat disimpulkan bahwa variabel CSR*KM tidak berpengaruh terhadap ABNPROD, sehingga H2 yang menyatakan bahwa kepemilikan manajerial memperkuat pengaruh negatif antara pengungkapan CSR dan manajemen laba riil (yang diproksikan dengan biaya produksi abnormal) ditolak. Variabel CSR ${ }^{*} \mathrm{KI}$ memperoleh nilai $\mathrm{t}$ sebesar -2,017 dan signifikansi sebesar 0,045. Dengan demikian dapat disimpulkan bahwa variabel CSR*KI berpengaruh negatif terhadap ABNPROD, sehingga H3 yang menyatakan bahwa kepemilikan institusional memperkuat pengaruh negatif antara pengungkapan CSR dan manajemen laba riil (yang diproksikan dengan biaya produksi abnormal) diterima.

Tabel 4.12 Hasil Uji t Persamaan 3a

\begin{tabular}{cccccc}
\hline Variabel & \multicolumn{2}{l}{$\begin{array}{l}\text { Unstandardized } \\
\text { Coef. }\end{array}$} & t & Sig. & Keterangan \\
\cline { 2 - 4 } & B & Std. Error & & & \\
\hline $\begin{array}{c}\text { (Constant } \\
\text { ) }\end{array}$ & $-0,202$ & 0,066 & $-3,071$ & 0,002 & \\
\hline CSR & 0,605 & 0,225 & 2,693 & 0,008 & Berpengaruh positif \\
\hline KM & 0,053 & 0,099 & 0,536 & 0,593 & Tidak berpengaruh \\
\hline KI & 0,112 & 0,063 & 1,777 & 0,077 & Tidak berpengaruh \\
\hline
\end{tabular}

Persamaan regresi yang terbentuk adalah sebagai berikut:

$$
\text { ABNDE }=-0,202+0,605 \mathrm{CSR}+0,053 \mathrm{KM}+0,112 \mathrm{KI}+\varepsilon
$$

Variabel CSR memperoleh nilai t sebesar 2,693 dan signifikansi sebesar 0,002. Dengan demikian dapat disimpulkan bahwa variabel CSR berpengaruh positif signifikan terhadap ABNDE. Semakin besar nilai CSR maka semakin besar juga nilai ABNDE. Manajemen laba riil diindikasikan dengan rendahnya nilai ABNDE (bernilai negatif). Dari hasil uji $\mathrm{t}$ dapat disimpulkan bahwa semakin tinggi nilai CSR maka semakin rendah manajemen laba riil melalui biaya diskresioner abnormal (semakin bernilai positif), sehingga H1 yang menyatakan bahwa pengungkapan CSR berpengaruh negatif terhadap manajemen laba riil (yang diproksikan dengan biaya diskresioner abnormal) diterima. Variabel KM memperoleh nilai t sebesar 0,536 dan signifikansi sebesar 0,593. Variabel KI memperoleh nilai t sebesar 1,777 dan signifikansi sebesar 0,077. Dengan demikian dapat disimpulkan bahwa variabel KM dan KI tidak berpengaruh terhadap ABNDE. 
Tabel 4.13 Hasil Uji t Persamaan 3b

\begin{tabular}{cccccc}
\hline Variabel & \multicolumn{2}{c}{$\begin{array}{c}\text { Unstandardized } \\
\text { Coef. }\end{array}$} & $\mathbf{t}$ & Sig. & Keterangan \\
\cline { 2 - 4 } & $\mathrm{B}$ & Std. Error & & & \\
\hline $\begin{array}{c}\text { (Constant } \\
\text { ) }\end{array}$ & 0,005 & 0,215 & 0,025 & 0,980 & \\
\hline CSR & $-0,470$ & 1,090 & $-0,431$ & 0,667 & Tidak berpengaruh \\
\hline KM & $-0,564$ & 0,918 & $-0,614$ & 0,540 & Tidak berpengaruh \\
\hline KI & $-0,156$ & 0,279 & $-0,561$ & 0,576 & Tidak berpengaruh \\
\hline CSR*KM & 3,271 & 4,897 & 0,668 & 0,505 & Tidak berpengaruh \\
\hline CSR $^{*}$ KI & 1,399 & 1,415 & 0,989 & 0,324 & Tidak berpengaruh \\
\hline
\end{tabular}

Persamaan regresi yang terbentuk adalah sebagai berikut:

ABNDE $=0,005-0,470 \mathrm{CSR}-0,564 \mathrm{KM}-0,156 \mathrm{KI}+3,271 \mathrm{CSR} * \mathrm{KM}+1,399 \mathrm{CSR}{ }^{*} \mathrm{KI}+\varepsilon$

Variabel CSR memperoleh nilai t sebesar -0,431 dan signifikansi sebesar 0,667. Dengan demikian dapat disimpulkan bahwa variabel CSR tidak berpengaruh terhadap ABNDE, sehingga H1 yang menyatakan bahwa pengungkapan CSR berpengaruh negatif terhadap manajemen laba riil (yang diproksikan dengan biaya diskresioner abnormal) ditolak. Variabel KM memperoleh nilai $\mathrm{t}$ sebesar -0,614 dan signifikansi sebesar 0,540. Variabel KI memperoleh nilai t sebesar -0,561 dan signifikansi sebesar 0,576. Dengan demikian dapat disimpulkan bahwa variabel KM dan KI tidak berpengaruh terhadap ABNDE. Variabel CSR*KM memperoleh nilai t sebesar 0,668 dan signifikansi sebesar 0,505. Dengan demikian dapat disimpulkan bahwa variabel CSR ${ }^{\star} \mathrm{KM}$ tidak berpengaruh terhadap ABNDE, sehingga $\mathrm{H} 2$ yang menyatakan bahwa kepemilikan manajerial memperkuat pengaruh negatif antara pengungkapan CSR dan manajemen laba riil (yang diproksikan dengan biaya diskresioner abnormal) ditolak. Variabel CSR*KI memperoleh nilai $t$ sebesar 0,989 dan signifikansi sebesar 0,324. Dengan demikian dapat disimpulkan bahwa variabel CSR*KI tidak berpengaruh terhadap ABNDE, sehingga $\mathrm{H} 3$ yang menyatakan bahwa kepemilikan institusional memperkuat pengaruh negatif antara pengungkapan CSR dan manajemen laba riil (yang diproksikan dengan biaya diskresioner abnormal) ditolak.

4.5. Pembahasan

4.5.1. Pengaruh Pengungkapan Corporate Social Responsibilty (CSR) terhadap Manajemen Laba Riil

Berdasarkan hasil pengujian hipotesis pada tabel 4.8 menunjukkan bahwa pengungkapan CSR berpengaruh positif signifikan terhadap arus kas operasi abnormal. Semakin banyak pengungkapan CSR yang dilakukan perusahaan maka nilai arus kas dari penerimaan atau pengeluaran perusahaan sehubungan dengan kegiatan operasional juga semakin tinggi yang mengindikasikan tidak adanya manajemen laba riil. Hipotesis pertama yang menyatakan bahwa pengungkapan CSR berpengaruh negatif terhadap manajemen laba riil diterima. Aktivitas-aktivitas perusahaan yang 
berhubungan dengan tanggung jawab sosial dilakukan sebagai bentuk kepedulian perusahaan terhadap lingkungan sekitar. Perusahaan melakukan pengungkapan atas aktivitas tanggung jawab sosialnya dalam laporan tahunan. Semakin banyak pengungkapan CSR yang diungkapkan perusahaan dalam laporan tahunan menunjukkan bahwa perusahaan semakin terbuka dan transparan terhadap para pengguna laporan sehingga hal ini dapat menurunkan adanya tindakan oportunistik atau manajemen laba yang dilakukan oleh manajemen perusahaan. Perusahaan yang telah berkomitmen untuk melakukan praktik CSR akan berperilaku etis dan akan mengurangi praktik manajemen laba (Ricardo dan Faisal, 2015). Salah satu bentuk manajemen laba yang dapat dilakukan oleh perusahaan yaitu melakukan pemanipulasian penjualan dengan adanya potongan harga atau diskon besar-besaran yang dapat menurunkan arus kas operasi sehingga arus kas operasi bernilai negatif. Arus kas operasi abnormal ditunjukkan dengan adanya pengelolaan penjualan untuk membuat angka penjualan meningkat, sehingga laba yang dihasilkan perusahaan juga akan meningkat (Mukhtar, 2016). Berdasarkan hasil analisis data, nilai rata-rata ABNCFO bernilai positif yang menunjukkan bahwa secara keseluruhan tidak terjadi manajemen laba riil ABNCFO pada periode penelitian 2016-2019 (indikasi adanya manajemen laba riil yaitu ketika nilai arus kas operasi abnormal bernilai negatif). Secara rata-rata banyaknya pengungkapan CSR yang dilakukan oleh perusahaan sampel dalam penelitian yaitu sebesar 18,5\% dari total 91 item pengungkapan. Nilai ABNCFO maupun CSR tersebut masih tergolong rendah, yang menunjukkan bahwa peningkatan ABNCFO dikarenakan pengaruh peningkatan pengungkapan CSR juga masih rendah. Perusahaan harus lebih banyak melakukan pengungkapan CSR, sehingga nilai arus kas operasi abnormal perusahaan juga akan meningkat hingga mencapai nilai positif yang mengindikasikan tidak terjadi manajemen laba riil melalui arus kas operasi. Hasil penelitian ini sejalan dengan penelitian Ricardo dan Faisal (2015), Sembiring (2017), Ardiani dan Sudana (2018) di mana pengungkapan CSR akan menurunkan kemungkinan terjadinya manajemen laba.

Berdasarkan hasil pengujian hipotesis pada tabel 4.10 menunjukkan bahwa pengungkapan CSR berpengaruh negatif signifikan terhadap biaya produksi abnormal. Semakin banyak pengungkapan CSR yang dilakukan perusahaan maka nilai biaya produksi abnormal semakin rendah yang mengindikasikan tidak adanya manajemen laba riil. Hipotesis pertama dalam penelitian yang menyatakan bahwa pengungkapan CSR berpengaruh negatif terhadap manajemen laba riil diterima. Aktivitas CSR yang dilakukan perusahaan bertujuan agar proses bisnis yang dilakukan perusahaan dapat berdampak positif terhadap masyarakat dan menjaga kelangsungan perusahaan (Tandry, dkk., 2014). Semakin banyak perusahaan melakukan pengungkapan CSR menunjukkan bahwa perusahaan memiliki transparasi yang cukup tinggi dalam laporan tahunan sehingga dapat mengurangi incentive manajer untuk melakukan tindakan oportunistik yaitu manajemen laba yang justru dapat merusak komitmen yang telah dibangun perusahaan (Sembiring, 2017). Salah satu bentuk manajemen laba 
yang dapat dilakukan oleh perusahaan yaitu melakukan teknik overproduction sehingga biaya produksi akan lebih tinggi dibandingkan dengan kondisi normal. Teknik overproduction ini sering dilakukan oleh perusahaan manufaktur untuk memperbesar laba dalam tahun berjalan. Hasil analisis data dalam penelitian ini menunjukkan nilai rata-rata ABNPROD bernilai positif yang menunjukkan adanya indikasi terjadi manajemen laba melalui biaya produksi walaupun tergolong rendah yaitu sebesar 0,1\%. Secara rata-rata banyaknya pengungkapan CSR yang dilakukan oleh perusahaan sampel dalam penelitian juga tergolong rendah yaitu sebesar 18,5\%. Hasil penelitian ini sejalan dengan penelitian Ricardo dan Faisal (2015), Sembiring (2017), Ardiani dan Sudana (2018) di mana pengungkapan CSR akan menurunkan kemungkinan terjadinya manajemen laba.

Berdasarkan hasil pengujian hipotesis pada tabel 4.12 menunjukkan bahwa pengungkapan CSR berpengaruh positif signifikan terhadap biaya diskresioner abnormal. Semakin banyak pengungkapan CSR yang dilakukan perusahaan maka nilai biaya diskresioner juga semakin tinggi (bernilai positif) yang mengindikasikan tidak adanya manajemen laba riil. Hipotesis pertama dalam penelitian yang menyatakan bahwa pengungkapan CSR berpengaruh negatif terhadap manajemen laba riil diterima. Perusahaan yang melakukan aktivitas-aktivitas sosial dan pengungkapan CSR menunjukkan bahwa perusahaan memiliki fokus terhadap kelangsungan lingkungan hidup dan hubungannya dengan para pemangku kepentingan (Tandry, dkk., 2014). Perusahaan yang berkomitmen untuk melakukan praktik CSR akan berperilaku etis dan akan mengurangi praktik manajemen laba (Irawan, dkk., 2021). Salah satu bentuk manajemen laba yang dapat dilakukan oleh perusahaan yaitu melakukan pengurangan biaya-biaya diskresioner yang dibebankan dalam periode berjalan untuk mencapai target laba tertentu (Majid, dkk., 2020). Berdasarkan hasil analisis data, nilai rata-rata ABNDE bernilai negatif yang menunjukkan bahwa secara keseluruhan terjadi manajemen laba riil melalui biaya diskresioner abnormal pada periode penelitian 20162019 sebesar -0,6\% (indikasi adanya manajemen laba riil yaitu ketika nilai biaya diskresioner abnormal bernilai negatif). Secara rata-rata banyaknya pengungkapan CSR yang dilakukan oleh perusahaan sampel dalam penelitian yaitu sebesar $18,5 \%$ dari total 91 item pengungkapan. Nilai ABNDE maupun CSR tersebut masih tergolong rendah, yang menunjukkan bahwa peningkatan ABNDE dikarenakan pengaruh peningkatan pengungkapan CSR juga masih rendah. Perusahaan harus lebih banyak melakukan pengungkapan CSR, biaya diskresioner abnormal perusahaan juga akan meningkat hingga mencapai hasil positif yang mengindikasikan tidak terjadi manajemen laba riil melalui biaya diskresioner. Hasil penelitian ini sejalan dengan penelitian Irawan, dkk. (2021), Ricardo dan Faisal (2015), Sembiring (2017), Ardiani dan Sudana (2018) di mana pengungkapan CSR akan menurunkan kemungkinan terjadinya manajemen laba dan sehingga tidak ada manipulasi informasi yang disajikan dalam lapora keuangan. 
4.5.2. Pengaruh Pengungkapan Corporate Social Responsibilty (CSR) terhadap Manajemen Laba Riil dengan Kepemilikan Manajerial sebagai Pemoderasi

Berdasarkan hasil pengujian hipotesis pada tabel 4.9 menunjukkan bahwa besar kecilnya kepemilikan manajerial tidak dapat memperkuat pengaruh pengungkapan CSR terhadap arus kas operasi abnormal, sehingga hipotesis kedua dalam penelitian yang menyatakan bahwa kepemilikan manajerial memperkuat pengaruh negatif antara pengungkapan CSR dan manajemen laba riil ditolak. Menurut Boediono (2005) motivasi yang dimiliki manajer yang memiliki saham perusahaan akan berbeda dengan manajer yang bukan sekaligus sebagai pemegang saham. Namun, kepemilikan saham oleh manajemen perusahaan tidak mampu mempengaruhi pengambilan keputusan oleh manajemen, salah satunya yaitu dalam menentukan keputusan dalam melakukan pengungkapan CSR yang dapat mengakibatkan penurunan tindakan manajemen laba riil. Berdasarkan hasil analisis data, nilai rata-rata ABNCFO bernilai positif yang menunjukkan bahwa secara keseluruhan tidak terjadi manajemen laba riil ABNCFO pada periode penelitian 2016-2019 (indikasi adanya manajemen laba riil yaitu ketika nilai arus kas operasi abnormal bernilai negatif). Secara rata-rata nilai kepemilikan manajerial perusahaan sampel cukup rendah yaitu 0,0386594. Hasil penelitian ini menunjukkan bahwa besar kecilnya nilai kepemikan manajerial tidak berpengaruh terhadap manajemen laba riil melalui arus kas operasi abnormal dan tidak memoderasi hubungan pengungkapan CSR dan arus kas operasi abnormal. Dalam penelitian ini walaupun nilai kepemilikan manajerial tidak besar, secara rata-rata perusahaan perusahaan juga tidak melalukan manajemen laba riil melalui arus kas operasi abnormal. Hal ini sejalan dengan penelitian Ardiani dan Sudana (2018) di mana kepemilikan manajerial tidak dapat memoderasi hubungan antara pengungkapan CSR dan manajemen laba.

Berdasarkan hasil pengujian hipotesis pada tabel 4.11 menunjukkan bahwa besar kecilnya kepemilikan manajerial tidak dapat memperkuat pengaruh pengungkapan CSR terhadap biaya produksi abnormal, sehingga hipotesis kedua dalam penelitian yang menyatakan bahwa kepemilikan manajerial memperkuat pengaruh negatif antara pengungkapan CSR dan manajemen laba riil ditolak. Menurut Andrianto dan Anis (2014) kepemilikan manajerial mampu membatasi manajemen untuk melakukan manajemen laba, sehingga manajemen perusahaan akan lebih berhati-hati dalam mengambil keputusan. Namun, kepemilikan saham oleh manajemen perusahaan tidak mampu mempengaruhi pengambilan keputusan oleh manajemen, salah satunya yaitu dalam menentukan keputusan dalam melakukan pengungkapan CSR yang dapat mengakibatkan penurunan tindakan manajemen laba riil. Hasil analisis data dalam penelitian ini menunjukkan nilai rata-rata ABNPROD bernilai positif yang menunjukkan adanya indikasi terjadi manajemen laba melalui biaya produksi walaupun tergolong rendah yaitu sebesar $0,1 \%$. Secara rata-rata nilai kepemilikan manajerial perusahaan sampel cukup rendah yaitu 0,0386594. Hasil penelitian ini menunjukkan bahwa dengan nilai kepemilikan manajerial cukup rendah, nilai 
manajemen laba riil melalui biaya produksi juga cukup rendah, sehingga dapat disimpulkan bahwa besar kecilnya nilai kepemilikan manajerial tidak berpengaruh terhadap manajemen laba riil melalui biaya produksi abnormal dan tidak memoderasi hubungan pengungkapan CSR dan biaya produksi abnormal. Hal ini sejalan dengan penelitian Ardiani dan Sudana (2018) di mana kepemilikan manajerial tidak dapat memoderasi hubungan antara pengungkapan CSR dan manajemen laba.

Berdasarkan hasil pengujian hipotesis pada tabel 4.13 menunjukkan bahwa besar kecilnya kepemilikan manajerial tidak dapat memperkuat pengaruh pengungkapan CSR terhadap biaya diskresioner abnormal, sehingga hipotesis kedua dalam penelitian yang menyatakan bahwa kepemilikan manajerial memperkuat pengaruh negatif antara pengungkapan CSR dan manajemen laba riil ditolak. Menurut Boediono (2005) motivasi yang dimiliki manajer yang memiliki saham perusahaan akan berbeda dengan manajer yang bukan sekaligus sebagai pemegang saham. Namun, kepemilikan saham oleh manajemen perusahaan tidak mampu mempengaruhi pengambilan keputusan oleh manajemen, salah satunya yaitu dalam menentukan keputusan dalam melakukan pengungkapan CSR yang dapat mengakibatkan penurunan tindakan manajemen laba riil. Berdasarkan hasil analisis data, nilai rata-rata ABNDE bernilai negatif yang menunjukkan bahwa secara keseluruhan terjadi manajemen laba riil ABNDE (indikasi adanya manajemen laba riil yaitu ketika nilai biaya diskresioner abnormal bernilai negatif) namun hanya sebesar $0,6 \%$. Secara rata-rata nilai kepemilikan manajerial perusahaan sampel cukup rendah yaitu 0,0386594. Hasil penelitian ini menunjukkan bahwa besar kecilnya nilai kepemilikan manajerial tidak berpengaruh terhadap manajemen laba riil melalui biaya diskresioner abnormal dan tidak memoderasi hubungan pengungkapan CSR dan biaya diskresioner abnormal. Hal ini sejalan dengan penelitian Ardiani dan Sudana (2018) di mana kepemilikan manajerial tidak dapat memoderasi hubungan antara pengungkapan CSR dan manajemen laba.

4.5.3. Pengaruh Pengungkapan Corporate Social Responsibilty (CSR) terhadap Manajemen Laba Riil dengan Kepemilikan Institusional sebagai Pemoderasi

Berdasarkan hasil pengujian hipotesis pada tabel 4.9 menunjukkan bahwa besar kecilnya kepemilikan institusional tidak dapat memoderasi hubungan antara pengungkapan CSR dan arus kas operasi abnormal, sehingga hipotesis ketiga dalam penelitian yang menyatakan bahwa kepemilikan institusional memperkuat pengaruh negatif antara pengungkapan CSR dan manajemen laba riil ditolak. Berdasarkan hasil analisis data, nilai rata-rata ABNCFO bernilai positif yang menunjukkan bahwa secara keseluruhan tidak terjadi manajemen laba riil ABNCFO pada periode penelitian 20162019 (indikasi adanya manajemen laba riil yaitu ketika nilai arus kas operasi abnormal bernilai negatif). Secara keseluruhan, perusahaan sampel memiliki rata-rata kepemilikan institusional yang cukup tinggi yaitu 72,4\%. Hasil penelitian ini menunjukkan bahwa besar kecilnya nilai kepemikan institusional tidak berpengaruh apakah akan terjadi manajemen laba riil melalui arus kas operasi abnormal dan tidak 
memoderasi hubungan pengungkapan CSR dan arus kas operasi abnormal. Hasil penelitian ini sejalan dengan penelitian Buertey, dkk. (2019) di mana kepemilikan institusional tidak dapat memoderasi hubungan antara pengungkapan CSR dan manajemen laba.

Berdasarkan hasil pengujian hipotesis pada tabel 4.11 menunjukkan bahwa besar kecilnya kepemilikan institusional dapat memperkuat pengaruh negatif antara pengungkapan CSR dan biaya produksi abnormal, sehingga hipotesis ketiga dalam penelitian yang menyatakan bahwa kepemilikan institusional memperkuat pengaruh negatif antara pengungkapan CSR dan manajemen laba riil diterima. Hasil analisis data dalam penelitian ini menunjukkan nilai rata-rata ABNPROD bernilai positif yang menunjukkan adanya indikasi terjadi manajemen laba melalui biaya produksi walaupun tergolong rendah yaitu sebesar $0,1 \%$. Secara keseluruhan, perusahaan sampel memiliki rata-rata kepemilikan institusional yang cukup tinggi yaitu $72,4 \%$. Hal ini menunjukkan bahwa semakin tinggi kepemilikan institusional maka manajemen laba riil melalui biaya produksi akan semakin kecil. Hasil penelitian ini menunjukkan bahwa besar kecilnya nilai kepemilikan institusional dapat memperkuat pengaruh negatif CSR dengan biaya produksi abnormal. Hasil penelitian ini sejalan dengan penelitian Sembiring (2017), Ardiani dan Sudana (2018) di mana kepemilikan institusional mampu memperkuat hubungan negatif antara pengungkapan CSR dan manajemen laba.

Berdasarkan hasil pengujian hipotesis pada tabel 4.13 menunjukkan bahwa besar kecilnya kepemilikan institusional tidak dapat memoderasi hubungan antara pengungkapan CSR dan biaya diskresioner abnormal, sehingga hipotesis ketiga dalam penelitian yang menyatakan bahwa kepemilikan institusional memperkuat pengaruh negatif antara pengungkapan CSR dan manajemen laba riil ditolak. Berdasarkan hasil analisis data, ABNDE bernilai negatif yang menunjukkan bahwa secara keseluruhan terjadi manajemen laba riil ABNDE pada periode penelitian 2016-2019 (indikasi adanya manajemen laba riil yaitu ketika nilai biaya diskresioner abnormal bernilai negatif). Secara keseluruhan, perusahaan sampel memiliki rata-rata kepemilikan institusional yang cukup tinggi yaitu 72,4\%, namun masih terjadi manajemen laba riil melalui biaya diskresioner abnormal. Hasil penelitian ini menunjukkan bahwa besar kecilnya nilai kepemikan institusional tidak berpengaruh terhadap terjadinya manajemen laba riil melalui biaya diskresioner abnormal dan tidak memoderasi hubungan pengungkapan CSR dan biaya diskresioner abnormal. Hasil penelitian ini sejalan dengan penelitian Buertey, dkk. (2019) di mana kepemilikan institusional tidak dapat memoderasi hubungan antara pengungkapan CSR dan manajemen laba.

\section{Kesimpulan, Keterbatasan, dan Saran}

\subsection{Kesimpulan}

Berdasarkan hasil analisis serta pembahasan dapat disimpulkan bahwa hipotesis pertama yang menyatakan bahwa pengungkapan CSR berpengaruh negatif terhadap 
manajemen laba riil yang diproksikan melalui arus kas operasi abnormal, biaya produksi abnormal, dan biaya diskresioner abnormal diterima. Perusahaan yang melakukan aktivitas-aktivitas CSR dan melakukan pengungkapan dalam laporan keuangan menunjukkan bahwa perusahaan semakin terbuka dan transparan terhadap para pengguna laporan sehingga dapat menurunkan adanya manajemen laba yang dilakukan oleh manajemen perusahaan. Hipotesis kedua yang menyatakan bahwa kepemilikan manajerial memperkuat pengaruh negatif antara pengungkapan CSR dan manajemen laba riil yang diproksikan melalui arus kas operasi abnormal, biaya produksi abnormal, dan biaya diskresioner abnormal ditolak. Hal ini menunjukkan bahwa adanya kepemilikan saham oleh pihak manajemen tidak menjamin akan dilakukannya manajemen laba riil oleh perusahaan atau tidak. Hipotesis ketiga yang menyatakan bahwa kepemilikan institusional memperkuat pengaruh negatif antara pengungkapan CSR dan manajemen laba riil yang diproksikan melalui biaya produksi abnormal diterima, sedangkan untuk manajemen laba riil yang diproksikan oleh arus kas operasi abnormal dan biaya diskresioner abnormal hipotesis ketiga ditolak. Hal ini dikarenakan tidak semua pemegang saham institusi dapat memberikan pengawasan yang baik kepada manajemen perusahaan.

\subsection{Keterbatasan}

Penelitian ini hanya menguji satu variabel independen yaitu pengungkapan corporate social responsibility serta variabel moderasi yaitu mekanisme corporate governance yang terdiri dari kepemilikan manajerial dan kepemilikan institusional. Di luar variabel tersebut masih terdapat kemungkinan variabel lain yang dapat mempengaruhi manajemen laba riil. Objek dalam penelitian ini hanya terbatas dikarenakan adanya kriteria-kriteria tertentu yang ditetapkan. Beberapa hasil uji asumsi klasik dalam penelitian ini yaitu uji normalitas, uji heteroskedastisitas, dan uji autokorelasi untuk beberapa persamaan tidak lolos, namun data yang digunakan dalam penelitian ini berjumlah lebih dari 30 dan menggunakan data panel sehingga dapat diasumsikan lolos uji asumsi klasik.

\subsection{Saran}

Peneliti selanjutnya disarankan untuk menambahkan dan menguji variabel independen atau variabel moderasi lain yang dapat berpengaruh terhadap manajemen laba riil, misalnya menggunakan proksi lain dari mekanisme corporate governance yakni dewan komisaris independen (Buertey, dkk., 2019) atau menggunakan variabel moderasi lain seperti karakteristik perusahaan (Ricardo dan Faisal, 2015). Peneliti selanjutnya disarankan untuk memperpanjang periode penelitian agar dapat menujukkan kekonsistenan pengungkapan lingkungan oleh perusahaan dan menunjukkan apakah terdapat pola manjemen laba riil yang dilakukan oleh perusahaan.

\section{Daftar Pustaka}


Ardiani, N.L.N., dan I.P. Sudana. 2018. Pengaruh Corporate Social Responsibility pada Manajemen Laba. E-jurnal Akuntansi Universitas Udayana. Vol. 24 No. 3: 2333-2359.

Buertey, S., E.J. Sun, J.S. Lee, dan J. Hwang. 2019. Corporate Social Responsibility and Earnings Management: The moderating Effect of Corporate Governance Mechanisms, Corporate Social Responsibility and Environmental Management (May): 256-271.

Dewi, L. C., dan Y.W. Nugrahanti. 2014. Pengaruh Struktur Kepemilikan dan Dewan Komisaris Independen terhadap Nilai Perusahaan (Studi pada Perusahaan Industri Barang Konsumsi di BEI Tahun 2011-2013). KINERJA. Vol. 18 No. 1: 64-79.

Duwu, M.I., S.C. Daat., dan H.N. Andriati. 2018. Pengaruh Biological Asset Intensity, Ukuran Perusahaan, Konsentrasi Kepemilikan, Jenis KAP, dan Profitabilitas terhadap Biological Asset Disclosure, Jurnal Akuntansi dan Keuangan Daerah. Vol. 13 No. 2: 56-75.

Forum for Corporate Governance in Indonesia. 2001. Peranan Dewan Komisaris dan Komite Audit dalam Pelaksanaan Corporate Governance (Tata Kelola Perusahaan). Jakarta: FCGI.

Irawan, D., S.W.W. Astuti, dan N. Afifah. 2021. The Effect of Corporate Social Responsibility Disclosure on Earning Management and Firm Value: Evidence from Indonesia. Journal of Asian Finance, Economics and Business. Vol 8 No. 7: 0103-0109.

Kalbuana, N., M.W. Sutadipraja,, T. Purwanti, dan D. Santoso. 2019. Pengungkapan Islamic Social Reporting: Pengaruh Profitabilitas, Leverage, dan Kinerja Lingkungan (Studi Empiris pada Perusahaan yang Terdaftar di Jll Tahun 2013-2017). Vol. 2 No. 2: 233-248.

Launa, E., dan N.W. Respati. 2014. Pengaruh Mekanisme Corporate Governance dan Ukuran Perusahaan terhadap Manajemen Laba. Jurnal Reviu Akuntansi dan Keuangan. Vol. 4 No. 1: 507-524.

Magrath, L., dan L. G.Weld. 2002. Abusive Earnings Management and Early Warnings Signs. The CPA Journal. Vol. 72 No. 8: 51-54

Majid, M., S. Lysandra, I. Masri, dan W. Azizah. 2020. Pengaruh Kecapakan Manajerial terhadap Manajemen Laba Akrual dan Riil. Jurnal Imiah Akuntansi dan Manajemen Vol. 16 No.1: 70-84.

Manossoh, H. 2016. Good Corporate Governance Untuk Meningkatkan Kualitas Laporan Keuangan, Didapat dari http://repo.unsrat.ac.id/1133/1/BukuGood_corporate_governance_untuk_meningkatkan_ kualitas_laporan_keua ngan.pdf. 25 Oktober 2020. Pukul 20.00 WIB.

Mukhtar, N. 2016. Pengaruh Earning Power, Kecakapan Manajerial, dan Employee Stock Ownership Program terhadap Manajemen Laba Riil (Studi Empiris pada Perusahaan Manufaktur yang Terdaftar di Bursa Efek Indonesia tahun 2010-2014). Jurnal Akuntansi. Vol. 4 No. 1: 10-12.

Panda, B., dan N. M. Leepsa. 2017. Agency Theory: Review of Theory and Evidence on Problems and Perspectives. Indian Journal of Corporate Governance. Vol. 10 No. 1: 7495.

Puspitasari, A., dan Y.W. Nugrahanti. 2016. Pengaruh Hubungan Politik Ukuran KAP dan Audit Tenure terhadap Manajemen Laba Riil. Jurnal Akuntansi dan Keuangan. Vol. 18 No. 1: 27-43.

Putri, G.V., dan A. Rohman. 2016. Pengaruh Pengungkapan Corporate Social Responsibility dan Profitabilitas terhadap Manajemen Laba. Diponegoro Journal of Accounting. Vol. 5 No. 2: 1-11.

Ricardo, D.M., dan Faisal. 2015. Pengaruh Pengungkapan Corporate Social Responsibility terhadap Praktik Manajemen Laba. Diponegoro Journal of Accounting. Vol. 4 No. 3: 1-9. 
Roychowdhury, S. 2006. Earning Management Through Real Activities Manipulation. Journal of Accounting and Economics. Vol. 42 No. 3: 335-370.

Sembiring, C.L. 2017. Manajemen Laba dan Pengungkapan Tanggung Jawab Sosial Perusahaan dengan Komisaris Independen dan Kepemilikan Institusional sebagai Variabel Pemoderasi. Vol. 2 No. 1: 20-41.

Subiantoro, O. H., dan T. Mildawati. 2015. Pengaruh Karakteristik Perusahaan Terhadap Pengungkapan Corporate Social Responsibility. Jurnal IImu Dan Riset Akuntansi. Vol. 4 No. 9.

Suhardjanto, D. dan M. Wardhani. 2010. Praktik Intellectual Capital Disclosure Perusahaan yang Terdaftar di Bursa Efek Indonesia. Jurnal Akuntansi dan Auditing Indonesia. Vol. 14 No.1:71-85.

Tandry, A.Y., L. Setiawati, dan E. Setiawan. 2014. The Effect of CSR Disclosure to Firm Value with Earning Management As Moderating Variable: Case Study of Non-financing Firms Listed at Indonesia Stock Exchange. International Journal of Trade and Global Markets. Vol. 7 No. 3 . 